\title{
Goodwill impairment testing disclosures - South African compliance in 2018
}

\section{Charles Day}

Oxford Brookes Business School, Oxford Brookes University, Oxford, United Kingdom

Email:c.day@oxfordbrookes.ac.uk

This paper reviews compliance with the IAS 36 goodwill impairment testing disclosure requirements by South African entities included in the All Share Index of the Johannesburg Stock Exchange. A detailed extraction of disclosures provided by entities with material levels of goodwill was compared to the key requirements. The approach taken is grounded in an assumption that the diligence with which preparers attend to visible disclosures acts a "litmus test" of the reliability of the invisible workings of the "black box" of impairment testing. The results are analysed through a critical narrative proposing insights relevant to preparers, auditors, regulators, and standard-setters. Consistent with results of studies in other jurisdictions the disclosures of South African entities are often incomplete and inconsistent, presented in a minimalist, generic, "boiler-plate" fashion considered to be of limited use to decision makers assessing the reliability of impairment testing. This is the first known detailed review of South African levels of compliance with goodwill impairment testing disclosure requirements offered as an initial contribution to assessing the reliability of goodwill balances reported by South African corporate entities.

Keywords: Value in Use (VIU), Cash Generating Units (CGUs), Recoverable Amount, Discount Rates, Terminal Growth Rates 


\section{Introduction}

An indication of the challenges presented by accounting for goodwill is provided by this extract from an address by the Chairman of the International Accounting Standards Board (IASB): "goodwill is a mix of many things, including the internally generated goodwill of the acquired company and the synergy that is expected from the business combination. Usually, there is real value there, but nobody knows exactly how much. Most elements of goodwill are highly uncertain and subjective and they often turn out to be illusory" (Hoogervorst, 2012).

This reticence by the Chairman to robustly warrant the reliability of the value of goodwill manifests itself as unreserved cynicism in the pages of the influential publications, The Financial Times and The Economist. The Financial Times (Ford, 2018) characterises goodwill as a "hope value" and impairments as optional due to the discretion afforded managers to effectively monitor their own efforts unrestrained by acquiescent auditors. This optionality is seen to have real costs to creditors by enabling management and shareholders to receive inappropriate bonuses and dividends not justified by the underlying reality of the company. If greater confidence in the reported values is desired, then changes to the accounting rules are indicated. The Financial Times (Lex, 2010) is even more forthright in the aftermath of the great recession strongly suggesting that the reason for the surprisingly low incidence of impairments is the familiar, unchallenging relationship auditors have with clients. The Economist (2013) similarly impugns the ineffectiveness of auditors in standing up to their clients but has harsher words for the contrary actions of management - when impairments occur management is seen to dismiss them as mere accounting adjustments with no cash outflows yet equally is seen to take great lengths to avoid these ostensibly irrelevant impairments.

It should be of great concern to the accounting profession that these eminent publications express such a lack of faith in the reliability of an important aspect of financial reporting. It is opined that financial reporting, as with the metaphorical chain, is only as strong as its weakest link. If users doubt some elements of financial reports it seems reasonable to assume this doubt could spread and undermine the credibility of financial reporting as a whole. 
This paper aims to contribute to the debate required to achieve credibility with regard to goodwill accounting by providing an assessment of the goodwill impairment testing disclosure practices of companies listed on the Johannesburg Stock Exchange (JSE). A brief overview is provided of the nature and significance of goodwill and the related impairment testing and prior research in other jurisdictions into the levels of compliance with the mandatory disclosure requirements. The specific data and methodology employed in this paper will be presented, followed by a detailed analysis of the findings. The paper will conclude with an assessment of the results and the opportunities for future research arising from these findings.

\section{Theoretical background}

Goodwill, or to be precise, purchased goodwill, which is distinct from internally generated goodwill, arises when a business combination occurs for which International Financial Reporting Standard (IFRS) 3 Business Combinations compels the acquiring entity to use the acquisition method (IASB, 2018a). Goodwill is defined as an asset representing the future economic benefits arising from the other assets acquired that are not identified individually and recognised separately. The Basis for Conclusions in IFRS 3 describes six components that could comprise goodwill with component six, overpayment, being highly relevant to impairment testing. Also, of importance are the components seen to comprise core goodwill. Component three, is the fair value of the going concern element of the existing business acquired. Component four relates to the synergies and other benefits expected to be derived. A subsequent need to impair goodwill, likely indicates poor performance related to acquisitions with adverse implications for CEO compensation (Darrough, Guler, \& Wang, 2014). Management therefore has a vested interest in avoiding impairments related to acquisitions they were involved in acquiring or managing.

The bland language used in IFRS 3 to describe goodwill does not reflect the controversy and passion that goodwill has engendered in the past and continues to do so. Disagreement stems from two questions (Bloom, 2008) - first, is goodwill an asset; and second, if so, should it be amortised? The latest situation - though perhaps not final resolution if the title of the European Financial Reporting Advisory Group (EFRAG)'s report "Should Goodwill Still Not Be Amortised? Accounting and Disclosure for Goodwill" (EFRAG, 2014) is any indication - came about in 2004 with the adoption of IFRS 3 and revisions to IAS 36 Impairment of Assets. This mandated the use 
of the purchase method and eliminated the amortisation of goodwill over the assessed useful life instead requiring an annual impairment test. International studies indicating that this change has been value relevant are supported by studies by Eloff and de Villiers (2015) and Omarjee and Garnett (2017) that indicates this also applies in the South African context.

An impairment exists if the carrying amount exceeds the recoverable amount which is the higher of value in use (VIU) and fair value less costs of disposal (FVLCD). The mechanics of each method are not reviewed here except to note that both afford management considerable discretion due to the unverifiable nature of the future projections involved. This discretion, common to both US GAAP and IFRS impairment testing, could enable managers to convey private information that expected future cash flows are such that impairment is not required (Ramanna \& Watts, 2012). Contrary to this, managers may, consistent with agency theory, exploit the dependence of the impairment test on management estimates.

In an IFRS context, the European financial regulator, European Securities and Markets Authority (ESMA) (2013), notes that a book equity to market ratio exceeding 100\% can indicate that assets are impaired. While recognising that this is only one indicator of possible impairment which does not inevitably result in impairment, ESMA questioned whether the impact of the financial and economic crisis had been adequately captured in the financial statements examined.

It is suggested that this reliance on market prices to indicate impairment is an unsatisfactory reversal of the intended roles - financial reports should communicate impairments to users in a timely manner rather than belatedly process accounting impairments for the economic impairments already assessed by the market. Additionally, strong performance in most areas of an entity can mask indicated impairments for individual cash-generating units (CGUs). Addressing this issue, Ji (2013), using a disaggregated analysis to identify "mini-firms", found the absence of impairment despite poor performance indicative of impairment delay and avoidance.

The bulk of the IFRS research - such as Carlin and Finch (2007, 2011), D'Alauro (2013), Glaum, Schmidt, Street, \& Vogel., (2013), Mazzi, André, Dionysiou, \& Tsalavoutas (2017) - has focused on disclosures consistent with the motivation in IAS 36 BC201 to require information to assist 
users' evaluation of the reliability of goodwill. Carvalho, Rodriques, \& Ferreira (2016), in their critical analysis of the literature, on disclosures of goodwill and related impairment testing, published from 2002 to mid-2015, classify the studies into three sub-groups. The first adopts the use of a, weighted or not, disclosure index; the second involves a descriptive analysis of disclosure practices and compliance; and, the third comprises reports from major institutions and professional firms. The typical items tested were CGU identification and allocation, recoverable amount method, discount and growth rates, period covered, and sensitivity analysis. Poor compliance is seen across a range of countries indicating the presence of systemic rather than individual national issues. A common thread is the tendency to reproduce generic, rather than provide specific, information. A noteworthy observation is the absence of research into the relevance to the financial markets of the required disclosures (Carvalho et al., 2016).

In this paper a descriptive analysis approach is adopted. This paper borrows from the approach followed by Carlin and Finch (2011), in challenging the apparent compliance with discount disclosure requirements suggesting that the use of the same discount rate for all testing units is not consistent with the requirement to adapt the discount rate to the risk profile followed by the particular testing unit. This has been extended to the other disclosure requirements reviewed with the aim of reviewing whether prima facie compliance represents effective compliance consistent with the information needs of users. The often-binary scoring of impairment disclosures reported used in some studies is not considered optimal to capture the range of diverse responses that entities have reported. Scoring is seen to have merit where insights on correlations or causation are sought or where a comparison across country, auditor, industry, or size is desired. The aim of this paper is to produce an overall picture of South African impairment testing disclosures and therefore a descriptive approach is considered appropriate.

The key gap in the literature that this paper seeks to fill is the absence of a survey of goodwill impairment testing practices by South African entities. South Africa is a leading accounting nation as evidenced by its membership of the Global Accounting Alliance (www.globalaccountingalliance.com) and therefore insights into its goodwill impairment testing disclosures should be of interest. It is, however, also a country in which the reputation of the accounting profession has recently been tarnished with several prominent accounting scandals - 
Steinhoff, EOH, Tongaat, VBS, Resilient (Crotty, 2019). Considering the scope for managerial discretion and auditor acquiescence in goodwill impairment testing it is suggested the scope of this paper is timely and relevant.

\section{Significant data and methodology used}

The objective of, and approach followed in, this paper is aligned with the rationale of D'Alauro (2013) who suggests that disclosure can be seen as a "litmus test" indicating the faithfulness with which firms have conducted the impairment test. The author finds a positive correlation between the level of impairment test disclosures and the magnitude of goodwill impairments by entities with market indications of goodwill impairment. However, the contrary finding of Kabir, Rahman, $\& \mathrm{Su}$ (2017) is acknowledged, that firms with an understated goodwill impairment loss have higher goodwill impairment test-related disclosures and vice versa - disclosures are seen to be used to enhance the credibility of the goodwill impairment loss when it is understated.

This paper reviews the goodwill disclosures of 83 South African entities in the All Share Index with goodwill balances exceeding $1 \%$ of the value of total assets. The initial population consisted of the 134 domestic entities in the JSE All Share Index (JSE, 2018a). The All Share Index was selected as it was designed to represent the performance of South African companies and accounts for $99 \%$ of the full market capital value of all ordinary securities listed on the JSE (FTSE Russell, 2019). Included in the 163 entities comprising the index are 29 entities incorporated under the legislation of other countries. The objective of this paper is to review South African compliance levels and therefore these foreign entities have been excluded and the scope limited to domestic entities. A domestic entity is a limited company incorporated in the Republic of South Africa, subject to the provisions of the Companies Act, 2008, and audited by an auditor registered with the Independent Regulatory Board for Auditors.

The financial statements for the financial year-ends in 2018 were obtained from the investor relations website of each of the 134 South African entities and reviewed to assess the level of goodwill. One entity was a recent spinoff not due to prepare its initial financial statements until 2019. 29 entities were excluded as they had no goodwill and a further 21 had a goodwill balance representing less than $1 \%$ of total assets. Materiality is an appropriate consideration when 
reviewing compliance with IFRS disclosure requirement. Paragraph 31 of IAS 1 empowers an entity not to provide a disclosure required by a standard if the resulting information is not material. It is clarified that this exemption on the grounds of immateriality applies even when a standard contains a list of specific requirements as is the case with IAS 36 paragraph 134. A goodwill materiality threshold of $1 \%$ of total assets has therefore been used as a filter to eliminate entities where the immateriality of goodwill might be offered as justification for non-compliance. This $1 \%$ of total assets is consistent with the level used by PWC in its 2018 audit of Tradehold Limited (Tradehold, 2018). (PWC being the only audit firm seen to disclose materiality and Tradehold Limited being the only entity where total assets were used as the basis for determining materiality.) A $1 \%$ threshold is also aligned with the $1.1 \%$ average of the midpoints of the ranges used by eight major U.S. audit firms surveyed by Eilifsen and Messier (2015).

The financial statements of the remaining 83 entities were reviewed against the disclosure requirements detailed in paragraph 134 of IAS 36 (IASB, 2018a). The specific disclosures required by paragraph 134 for those CGUs or groups of units assessed to be significant which have been reviewed in this paper are:

(a) the goodwill carrying amount;

(c) the basis used to determine the recoverable amount;

(d) if VIU has been used, then:

(i) each key assumption on which cash flow projections have been based;

(ii) a description of the approach followed to determine the value of each key assumption and whether (and, if not, why not) these values are consistent with past experience and external sources;

(iii) the period covered by financial budgets and, if greater than five years, a justification;

(iv) the growth rate used for the period beyond that covered by financial budgets and justification if the rate exceeds the relevant long-term average growth rate;

(v) the discount rates.

Paragraph 134(b) relates to intangible assets with indefinite useful lives which is not within the scope of this paper. Paragraph 134(e) specifies the disclosures required if FVLCD is used. This 
has been excluded from the scope of this paper in the interest of brevity and justified because of the low level of application and diversity of practice seen in South African entities. Inadequate paragraph 134(d)(i) disclosures were seen to have an inevitable impact on the quality of the disclosures required by paragraph 134(f) if a reasonably possible change in a key assumption would cause the carrying amount to exceed the recoverable amount. Compliance with paragraph 134(f) has therefore not been reviewed.

The results of the survey of disclosure practices by the sample entities pursuant to these key requirements is presented and discussed in the following section.

\section{Major findings}

\subsection{Materiality of goodwill}

It is proposed that the materiality of the goodwill balances in the South African context is an appropriate consideration to be incorporated when reviewing the compliance with the goodwill impairment testing disclosure requirements. This is consistent with the observation in the methodology discussion above that IAS 1 permits non-disclosure on the grounds of immateriality. Therefore, as an introduction to the detailed review, an analysis of the materiality levels of the entities covered by this paper is presented.

Table 1 below is calculated from the values for goodwill, total assets, and shareholders' equity extracted from the financial statements of the 133 domestic entities in the All Share Index and the market capitalisation obtained from the December 2018 Quarterly Index Review Paper Market (JSE, 2018a). Goodwill as a percentage of total assets, shareholders' equity, and market capitalisation is presented for groups of entities based on the significance of goodwill compared to total assets.

$\underline{\text { Table } 1 \text { - Relative value of goodwill balances }}$

Average* Goodwill \% of:

\begin{tabular}{cccrrr}
$\begin{array}{c}\text { Ranges of } \\
\text { Goodwill \% of } \\
\text { Total Assets }\end{array}$ & Count & Total Assets & $\begin{array}{c}\text { Shareholders' } \\
\text { Equity }\end{array}$ & \multicolumn{2}{c}{$\begin{array}{c}\text { Market } \\
\text { Capitalisation }\end{array}$} \\
\hline $40 \%-49.9 \%$ & 1 & 46.8 & 76.4 & 62.3 \\
\hline
\end{tabular}




\begin{tabular}{|c|c|c|c|c|}
\hline $30 \%-39.9 \%$ & 5 & 33.7 & 65.2 & 72.5 \\
\hline $20 \%-29.9 \%$ & 7 & 26.1 & 54.6 & 41.6 \\
\hline $15 \%-19.9 \%$ & 1 & 15.3 & 34.0 & 30.3 \\
\hline $10 \%-14.9 \%$ & 13 & 11.6 & 26.9 & 15.8 \\
\hline $5 \%-9.9 \%$ & 22 & 7.2 & 20.1 & 15.9 \\
\hline $1 \%-4.9 \%$ & 34 & 2.7 & 11.5 & 6.9 \\
\hline Total Goodwill > 1\% & 83 & 9.8 & 24.1 & 18.5 \\
\hline$<1 \%$ & 21 & 0.3 & 2.8 & 2.4 \\
\hline Total all Goodwill & 104 & 7.9 & 19.8 & 15.3 \\
\hline $0 \%$ & 29 & - & - & \\
\hline Total All Domestic Entities & 133 & 6.2 & 15.5 & 11.9 \\
\hline
\end{tabular}

* Averages are simple (not weighted) calculated as the average of each of the percentages for each entity.

Goodwill balances, representing on average for each entity $7.9 \%$ of total assets, $19.8 \%$ of shareholders' equity, and 15.3\% of market capitalisation, occurred in 104 (78\%) of the 133 domestic entities. Goodwill is clearly a material asset to South African entities and therefore the diligence with which they provide the impairment testing disclosures reviewed below, and consequently, consistent with D'Alauro (2013), the integrity of impairment testing is important for the reliability of financial reporting.

\subsection{Carrying amount}

Goodwill is required, in accordance with paragraph 80 of IAS 36 (IASB, 2018a), to be allocated to CGUs in order that it can be subject to impairment testing. The units to which goodwill are assigned should represent the lowest level at which the goodwill is monitored for the internal management purposes of the entity. This presents an interesting question as to whether, and to what extent, entities actually monitor goodwill. Given that goodwill is an asset that cannot be sold individually to realise value, it may be that entities do not monitor goodwill in the manner envisaged in the standard. Possibly, monitoring only occurs because it is required by the standard. Carlin, Finch, \& Ford (2007) raise the prospect of a mutual contradiction between the requirement to allocate goodwill at the level that management monitors goodwill and the constraint that this level cannot be larger than an operating segment as defined in IFRS 8 Operating Segments (IASB, 2018a). The intent behind this restriction is to prevent avoidance of impairment through CGU aggregation. Carlin and Finch (2007) note the significant potential of CGU aggregation to explain deferred goodwill impairment. Aggregation of CGUs at a higher level enables less volatile segments to offset the volatility inherent in other segments thereby resulting in greater "head room" than would exist if CGUs were defined at a lower level. 
Paragraph 134(a) of IAS 36 (IASB, 2018a) requires the disclosure of the carrying amount of goodwill for each CGU that has a carrying amount that is significant in comparison to the total carrying amount of goodwill. Paragraph 135(a) of IAS 36 (IASB, 2018a) requires the disclosure of the aggregate carrying amount of goodwill that is not significant in comparison to the total carrying amount. The combination of paragraphs 134(a) and 135(a) is taken to require the entity to report the entire carrying amount of goodwill distinguishing between those named CGUs considered significant and the aggregated other entities considered insignificant.

Table 2 below presents the results of the survey of three elements of the reporting related to CGUs. First is the requirement to disclose the carrying amount of goodwill allocated to CGUs considered significant in comparison to total goodwill and the aggregate carrying amount of units with goodwill balances considered not significant. Second, the level at which goodwill balances have been reported which provides an insight into whether CGU aggregation is present in the South African reporting context. The third element is the nature of the CGUs reported. This last aspect is not a requirement of paragraph 134 concerning disclosures related to the impairment testing process. It is however, a requirement of paragraph 130(d)(i) which applies when an impairment loss is recognised, to provide a description of the CGU, such as whether it is a geographic area, product line, or business operation. This has been surveyed to provide insights into the types of units on which South African entities perform impairment testing. It is suggested that delaying the requirement to provide this description until an impairment has occurred is counter to the information needs of the users of the financial statements. These would be better served by including a requirement to provide this description with the impairment testing, rather than impairment loss, disclosures.

$\underline{\text { Table } 2 \text { - Goodwill reporting and testing levels }}$

Response to requirements to disclose the carrying amount of goodwill allocated to CGUs considered significant in comparison to total goodwill and the aggregate carrying amount of units with goodwill balances considered not significant

Compliant entities:

All goodwill allocated to reported CGUs or presented in aggregate as insignificant Substantially all goodwill allocated to reported CGUs

Initial carrying amounts on acquisition per CGU but not current amounts after impairments 


\begin{tabular}{|c|c|c|c|c|}
\hline \multicolumn{4}{|c|}{$\begin{array}{l}\text { Some CGU information presented but no monetary amounts in support of goodwill allocation } \\
\text { No CGU information presented }\end{array}$} & \multirow{2}{*}{$\begin{array}{r}3 \\
1 \\
83\end{array}$} \\
\hline Total all sample entities & & & & \\
\hline \multirow[b]{2}{*}{ Nature of the impairment testing unit } & \multicolumn{4}{|c|}{$\begin{array}{c}\text { Identification of the level at which the goodwill allocation } \\
\text { is reported }\end{array}$} \\
\hline & $\begin{array}{l}\text { Lower than } \\
\text { segment }\end{array}$ & $\begin{array}{l}\text { Segment } \\
\text { and lower }\end{array}$ & Segment & Total \\
\hline Informative nature of CGU description: & 24 & 1 & 23 & 48 \\
\hline Product group & 7 & & 13 & 20 \\
\hline Brand & 9 & & 3 & 12 \\
\hline Geographic unit & 2 & & 4 & 6 \\
\hline Mine & 3 & & & 3 \\
\hline Hospital / product group / geographic unit & & & 1 & 1 \\
\hline Product group / geographic unit & 1 & & & 1 \\
\hline Casino / hotel & & & 1 & 1 \\
\hline School / campus & & 1 & & 1 \\
\hline Trading site / cluster & 1 & & & 1 \\
\hline Institution & 1 & & & 1 \\
\hline Product group / school & & & 1 & 1 \\
\hline Partly informative / partly uninformative: & 2 & 1 & 1 & 4 \\
\hline Business unit / geographic unit & 1 & & 1 & 2 \\
\hline Legal entity / stores & 1 & & & 1 \\
\hline Product group / legal entity & & 1 & & 1 \\
\hline Uninformative nature of CGU description: & 24 & & 6 & 30 \\
\hline Business unit & 14 & & 5 & 19 \\
\hline Legal entity & 8 & & 1 & 9 \\
\hline Division & 1 & & & 1 \\
\hline Legal entity / business unit & 1 & & & 1 \\
\hline No CGU information presented: & & & & 1 \\
\hline Total all sample entities & 50 & 2 & 30 & 83 \\
\hline
\end{tabular}

78 of the 83 entities were seen to have complied with the requirement to disclose the goodwill carrying amount with the vast majority providing a listing of CGU balances which agreed to the total carrying amount of goodwill. Two of these 78 entities reported CGUs accounting for substantially all the goodwill balance. One entity disclosed the initial allocation of goodwill but did not allocate subsequent impairments and movements due to currency exchange differences. Four entities did not provide any details of the allocation of goodwill to CGUs although three of these did provide other information required by paragraph 134. None of the 82 entities reporting CGU information did so at a level above operating segment. 50 (61\% of 82) reported at a level below segment with 30 (37\% of 82$)$ reporting at a level below segment. Two entities reported goodwill at both the segment and lower than segment levels.

There were indications that some entities may have conducted impairment testing at a different 
level to that reported. These indications included: disclosures on impairment losses at a legal entity level contrasting with the higher level reported for impairment testing; lists of various units without carrying amounts comprising a broader total; reporting of ranges of discount and growth rates. IAS 36 makes it clear that the information to be provided is at the CGU level. This is reiterated by the ESMA (2012) enforcement order EECS/0112-09 that CGUs, containing significant amounts of goodwill, that were smaller than operating segments, had to be disclosed. This disclosure was required regardless of the confidentiality considerations claimed by the issuer. As an illustration of why this distinction matters, an entity with a significant percentage of goodwill to total assets (23.5\%) presents, for one segment, a discount rate range of $6.0 \%$ to $12.0 \%$ and for another a discount rate ranging from $7.5 \%$ to $19.9 \%$. It is difficult to envisage how such broad disclosures can be of any relevance to the users of the financial reports.

Considerable diversity is seen in the testing units disclosed. A distinction is drawn between units that may be considered to be more intuitive based on the names of the units and those where the names did not have any information content to a user unfamiliar with the details of the entity. Examples of the former are brands, product groups, geographic units, mines, casinos, stores, and campuses. It is suggested that these are meaningful units that will provide readers with some insight into the activities of the unit. In contrast, the use of legal entity and business unit names typically provides no insight into what these units do. 48 (59\% of 82 ) entities reported CGUs assessed to be informative with 30 (37\% of 82 ) reporting CGU names not seen to provide information on the nature of the testing unit. Four entities spanned both informative and uninformative CGU descriptions.

The Ontario Securities Commission (OSC) (2013) urges reporting entities to refrain from boilerplate descriptions of the approach taken to determining CGUs and instead provide real specificity about the nature and reasoning for the level at which CGUs have been identified. As noted above IAS 36 paragraph 130(d) only requires this information when an impairment has taken place. However, in the absence of the suggested inclusion in paragraph 134, it is argued that, consistent with the OSC guidance and good accounting policy note practice, disclosures would be significantly enhanced by voluntary provision of a meaningful description of what the applicable CGUs entail. 
The retail industry provides an interesting perspective on the, arguably undue, flexibility afforded reporting entities in assessing the level at which to test goodwill for impairment. Of the nine retail groups, comprising prominent chains of stores in the food, health, clothing, and hardware supply markets, only two test at an individual store or trading site level with the remainder testing at a higher level. Example 1 of the Illustrative Examples in IAS 36 (IASB, 2018a) clearly indicates that a retail store would be considered a CGU by virtue of the independent nature of the cash inflows of each store. EY (2017) notes the importance of considering cash inflows to avoid the common error of arguing that purchasing synergies link the stores within a chain and that they therefore are not independent. The case for considering stores not independent would require an assessment that if a store was closed down all the customers of that store would transfer their business to another store in the chain. However, Example 1 of the Illustrative Examples in IAS 36 (IASB, 2018a) also makes it clear that if management professes to monitor goodwill at a higher level, then that higher level is used for the impairment testing of goodwill.

It may be reasonable to have some sympathy for management in this regard. Firstly, given that goodwill can be considered not to be a real asset, capable of active management and severability, it could be argued that allocation down to a detailed level is a pointless and time-consuming exercise and that taking advantage of the option offered by IAS 36 is a justifiable and, indeed, responsible action. Against this it could be argued that goodwill is an integral and real, actual cost of the store and that active monitoring of the return on investment provided by each store requires goodwill to be allocated to the store level. This would have the additional benefit that if an individual store is impaired the full impact is recognised by management and communicated to the users. Secondly, it could be asserted that there is a contradiction between the requirement of paragraph 80 (IASB, 2018a) to allocate goodwill on the basis of the synergies expected to be realised and the focus on cash inflows in the definition of a CGU. ESMA (2014) does not afford management any leniency in this regard, clearly opining in enforcement order EECS/0114-04 that each individual branch was to be considered a separate CGU despite the existence of some income which was dependent on the branded business as a whole. Management was seen to monitor and make decisions about assets and operations at the individual branch level. 


\subsection{Recoverable amount basis}

Table 3 below sets out the basis used by the 83 entities to calculate the recoverable amount of the CGUs to which goodwill had been allocated.

\section{$\underline{\text { Table } 3 \text { - Basis used to calculate recoverable amount }}$}

\begin{tabular}{|c|c|c|c|}
\hline $\begin{array}{l}\text { Response to requirement to disclose basis on } \\
\text { which recoverable amount determined }\end{array}$ & VIU & FVLCD & Total* \\
\hline Basis clearly provided: & 70 & 14 & 76 \\
\hline VIU & 62 & & 62 \\
\hline Both & 8 & 8 & 8 \\
\hline FVLCD & & 6 & 6 \\
\hline Basis not clearly provided: & 4 & 2 & 5 \\
\hline Appears FVLCD but not specifically stated & & 1 & 1 \\
\hline Appears VIU but not specifically stated & 3 & & 3 \\
\hline Unclear which applied - data provided for both & 1 & 1 & 1 \\
\hline Basis provided both clearly and unclearly & 74 & 16 & 81 \\
\hline Basis not provided & & & 2 \\
\hline Total & 74 & 16 & 83 \\
\hline
\end{tabular}

* Total is not the sum of VIU and FVLCD due to entities using both bases.

$76(92 \%$ of 83$)$ of reporting entities clearly complied with the requirement to disclose the basis on which the recoverable amount was determined. Two entities did not provide any information stating or implying the basis used. Five (6\% of 83 ) entities did not clearly state which method was used. The information provided suggests that one of these used FVLCD and three used VIU. One entity provided information for both methods with no indication as to which of the two methods was the higher.

VIU was the dominant method used by 74 of the 81 entities reporting the basis used whether clearly or unclearly. Of this 74, 65 entities used VIU exclusively and 9 entities also used FVLCD. This $74(91 \%$ of 81$)$ is aligned with the findings of Carlin and Finch (2011) that $90 \%$ of the large listed Australian firms in their sample used VIU.

It is an open question as to the extent the predominant use of VIU is an indication that it resulted in the higher recoverable amount consistent with the intent of IAS 36. It would be insightful to understand the extent to which VIU was the only basis used, either because it produced a recoverable amount in excess of carrying amount, thereby eliminating the need to calculate 
FVLCD, or due to a misunderstanding of the nature and scope of fair value. There were indications that some preparers believe that fair value requires an active market. An entity stated that VIU was used "in the absence of an active market". One entity referred to the difficulty arising as "no reliable estimate" of FVLCD is obtainable and another expressed a similar concern that a realisable estimate is "not easily obtainable". Such concerns would likely not resonate with peers in the USA who only have the option to use fair value under US GAAP to determine the recoverable amount.

Two entities used the term "discounted cash flow basis" as a synonym for VIU possibly indicating a lack of awareness that a discounted cash flow is compatible with determining fair value in accordance with IFRS 13 Fair Value Measurement. Indeed, IAS 36 paragraph 134(e) requires certain disclosures if a discounted cash flow approach is used to measure FVLCD. The difference between the use of discounted cash flows in VIU and that for FVLCD is that VIU imposes conditions - pre-tax discount rate, cash flows to reflect the current state and not include future enhancements or restructuring, and an assumption that use of budgets will be for a maximum of five years. FVLCD, in contrast, imposes no such restrictions. The prohibition on inclusion of cash flows that would result from future restructuring or enhancements is proposed to be a major reason why preparers would be expected to use FVLCD.

However, while a valid practical consideration, an increased uptake in the use of FVLCD would raise an interesting philosophical issue. If FVLCD, exceeds VIU and, is indeed a valid estimate of what could be realised by selling rather than retaining and using the CGU or group of CGUs, then management would maximise shareholder value by selling the CGU or group. The IASB (2018b) in assessing whether to remove the requirement to exclude these cash flows noted its prior acknowledgement in 2004 that the VIU of a newly acquired unit would typically be lower than the FVLCD which indicated an inconsistency in the objective of determining whether it was better to sell an asset or keep using it. In their assessment, the IASB staff express the view that the inclusion of the potential enhancement or restructuring is not necessarily incompatible with the VIU concept. They assess that the prohibition imposed by IAS 36 may instead be a means to restrain management's ability to forecast unjustifiably optimistic cash flows and argue that this restraint is the responsibility of auditors and regulators and not the accounting standard. A regulator, the Australian Securities \& Investments Commission (2017), echoes this concern by cautioning 
preparers against using FVLCD as a means to employ unreliable estimates that would not be appropriate under a VIU model. The IASB staff conclude that the current requirement to split management's cash flow budgets and forecasts into maintenance and expansionary elements is counter to the intent in IAS 36 to integrate the VIU calculation with the regular budgeting and forecasting process, creates an unnecessary burden on management, and may be considered to produce less useful information.

\subsection{Cash flow projection period}

Table 4 below sets out the cash flow period for which a financial budget or forecast has been used by the 74 entities using VIU. It further indicates whether a justification has been provided where that period exceeds five years. This justification is required as a consequence of the IASB's assessment, stated in IAS 36 paragraph 35, that robust financial projections are typically not available for periods extending beyond five years. Management is permitted to use periods in excess of five years if it has confidence, and can substantiate past performance, in its ability to accurately project cash flows for such longer periods.

\section{$\underline{\text { Table } 4 \text { - VIU cash flow period }}$}

Response to requirement to disclose period over which management has projected cash flows based on budgets / forecasts
Justification for period exceeding 5 years?

$\begin{array}{cccc}\begin{array}{c}\text { Cash flow } \\ \text { period not } \\ \text { stated }\end{array} & \begin{array}{c}\text { Not } \\ \text { required }\end{array} & \begin{array}{c}\text { Required } \\ \text { but not } \\ \text { provided }\end{array} & \begin{array}{c}\text { Required } \\ \text { and } \\ \text { provided }\end{array}\end{array} \quad$ Total

Initial cash flow period 5 years or less

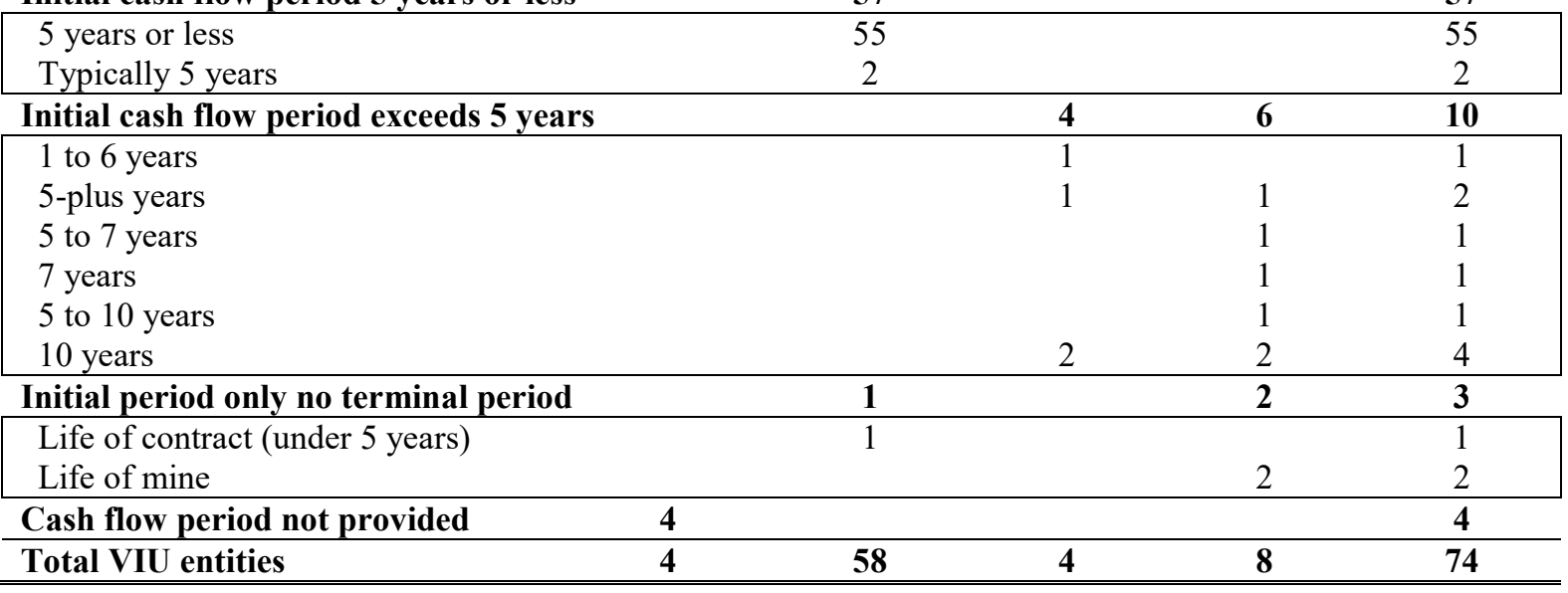

A clear majority 57 (77\%) of the 74 entities used a cash flow period of five years or less. This 
includes two entities employing the use of imprecise language, referring to "typically five years", which may not be considered to provide absolute assurance that the cash flow period was in fact five years or less. One entity used the life of the contract which was under five years. Four entities did not disclose the cash flow period used. A further 12 (16\% of 74$)$ entities used more than five years for some or all of the reported units. A sizeable minority, 4 (33\%) of these 12 did not provide the required justification for using a period greater than five years. These 12 entities included two where the cash flows were projected over the life of the mine with no distinction between the initial period covered by projected cash flows and an extrapolation of cash flows beyond this period.

This use of the life of mine period produced an interesting observation. One of the two mining entities using VIU and both of the FVLCD mining entities made a comment to the effect that allocation of goodwill to an individual mine will result in an eventual goodwill impairment due to the wasting nature of the mine. A further industry-specific observation relates to the retail sector. An entity that allocated goodwill to individual stores used a five to seven-year period, corresponding to the refurbishment cycles of the stores, with no extrapolation beyond this period as significant cash investments would be required. This would be rendered moot should the IASB proceed with removing the prohibition on cash flows resulting from enhancement or restructuring. However, in the absence of such change it could suggest that impairments may result towards the end of the refurbishment cycle.

\subsection{Discount rate}

Table 5 below sets out the discount rate disclosures observed in the 74 VIU entities.

$\underline{\text { Table } 5 \text { - VIU discount rate }}$

\section{Response to requirement to disclose the discounts rate(s) applied to the cash flow projections}

Clearly compliant:

Discrete discount rate for each CGU Justified single discount rate for all Ostensibly compliant:

Range of discount rates provided
Is a pre-tax rate reported as required?

\begin{tabular}{ccccc}
\multirow{2}{*}{ After-tax } & $\begin{array}{c}\text { Not stated } \\
\text { whether } \\
\text { pre- or } \\
\text { after-tax }\end{array}$ & $\begin{array}{c}\text { Largely } \\
\text { pre-tax; } \\
\text { one CGU } \\
\text { after-tax }\end{array} \quad$ Pre-tax & Total \\
& & &
\end{tabular}

\begin{tabular}{ccccc|}
$\mathbf{4}$ & $\mathbf{1 5}$ & $\mathbf{1}$ & $\mathbf{2 6}$ & $\mathbf{4 6}$ \\
\hline 4 & 14 & 1 & 24 & 43 \\
& 1 & & 2 & 3 \\
\hline $\mathbf{2}$ & $\mathbf{1 2}$ & & $\mathbf{1 3}$ & $\mathbf{2 7}$ \\
\hline 1 & 8 & & 7 & 16
\end{tabular}




\begin{tabular}{|lccccc|}
\hline $\begin{array}{l}\text { Single discount rate for all CGUs } \\
\text { Rate by geography not reported units }\end{array}$ & 1 & 4 & & 4 & 9 \\
Average not discrete discount rate & & & 1 & 1 \\
\hline $\begin{array}{l}\text { Compliant clearly and ostensibly } \\
\text { Clearly non-compliant: }\end{array}$ & $\mathbf{6}$ & $\mathbf{2 7}$ & $\mathbf{1}$ & $\mathbf{3 9}$ & $\mathbf{7 3}$ \\
\hline$\quad$ Discount rate not provided & $\mathbf{1}$ & 1 & & & 1 \\
\hline Total VIU Entities & $\mathbf{6}$ & $\mathbf{2 8}$ & $\mathbf{1}$ & $\mathbf{3 9}$ & $\mathbf{7 4}$ \\
\hline
\end{tabular}

73 of the 74 VIU entities report a discount rate applied to the cash flow projections. This compliance is classified into clear and ostensible compliance consistent with the argument of Carlin \& Finch (2011) that it is unlikely that all CGUs within an entity face the same risk profile and therefore use of a single rate is inappropriate. In this paper, it is argued further that provision of a range, particularly a wide range such as the $7.5 \%$ to $19.9 \%$ observed, is meaningless. Without the context provided by the size and nature of the CGUs and a direct relation to a specific discount rate, users are left with more questions than answers. Are $7.5 \%$ and $19.9 \%$ the only rates used? If not, what were the other rates? What was the relative significance of the rate ranges reported and other rates within the range?

Clear compliance is seen in 46 (62\% of the 74 VIU entities). Clear compliance is assessed where a discrete discount rate is disclosed for each reported CGU. Clear compliance was also assessed where a single rate for all CGUs was reported but this was justified based on a common risk profile. 27 (36\% of 74$)$ entities are classified as ostensibly compliant. Ostensible compliance results from the use of ranges of discount rates (16), a single rate for all CGUs (nine), reporting rates by geography instead of the units used in the impairment testing (one), and use of average discount rates (one).

The JSE (2017) reminds issuers that a pre-tax discount rate is to be used. Just over half the entities, 39 , confirmed the use of a pre-tax rate with six ( $8 \%$ of 74$)$ ignoring this requirement and using a post-tax rate. One entity reported the use of both pre- and after-tax rates for different CGUs. Paragraph 134 does not require the entity to confirm that the rate used was before tax - presumably, the clear directive in paragraph 55 to use a pre-tax rate is considered to render such confirmation redundant. A significant 28 (38\% of 74$)$ of the entities did not state that they had used a pre-tax rate - the question arises as to whether it is reasonable to assume that they were in compliance? 
IAS 36 provides a choice in dealing with the effect of inflation (paragraph 40) and risk (paragraph 55 ) - either the discount rate is adjusted, or the projected cash flows are. Again, in the absence of specific clarification the user may be left believing, but not sure, that the entity has followed the typical approach of including risk and inflation factors in the discount rate. A surprisingly low discount rate could be because the entity has adjusted cash flows for risk and inflation, but it could also be due to the use of an inappropriately low rate by the entity. A policy note clarification would eliminate such uncertainty.

\subsection{Extrapolation growth rate}

Table 6 below presents the disclosures seen in respect of the growth rate used for the terminal period after the initial period covered by budgets or forecasts. Also set out are the number of entities providing justification where the growth rate exceeded the relevant long-term average growth rate.

$\underline{\text { Table } 6 \text { - VIU growth rate }}$

\section{Response to requirement to disclose growth rate used to extrapolate cash flow projections beyond period covered by budgets / forecasts}

Comment in support of growth rate?

$\begin{array}{ccc}\begin{array}{c}\text { Rate } \\ \text { provided } \\ \text { but no } \\ \text { comment }\end{array} & \begin{array}{c}\text { Positive } \\ \text { assertion } \\ \text { in support } \\ \text { of rate }\end{array} & \begin{array}{c}\text { Rate not } \\ \text { required, } \\ \text { provided, } \\ \text { or unclear }\end{array}\end{array} \quad$ Total

\begin{tabular}{|lcccc|}
\hline Clearly compliant: & $\mathbf{1 5}$ & $\mathbf{1 9}$ & $\mathbf{3}$ & $\mathbf{3 7}$ \\
\hline Discrete growth rate for each CGU & 15 & 19 & & 34 \\
No terminal period - life of mine & & & 2 & 2 \\
No terminal period - life of contract & & & 1 & 1 \\
\hline Ostensibly compliant: & $\mathbf{1 5}$ & $\mathbf{1 2}$ & & $\mathbf{2 7}$ \\
\hline Same rate for all CGUs & 3 & 1 & & 4 \\
Range of growth rates reported & 7 & 4 & & 11 \\
Single rate for all CGUs & 5 & 6 & & 11 \\
Rate by geography not reported CGUs & & 1 & $\mathbf{3}$ & $\mathbf{6 4}$ \\
\hline Compliant clearly and ostensibly & $\mathbf{3 0}$ & $\mathbf{3 1}$ & $\mathbf{1 0}$ & $\mathbf{1 0}$ \\
\hline Clearly non-compliant: & & & 4 & 4 \\
\hline Not clear rate is for terminal period & & & $\mathbf{1 3}$ & $\mathbf{7 4}$ \\
$\quad$ Growth rate not provided & & $\mathbf{3 1}$ & & \\
\hline Total VIU entities & $\mathbf{3 0}$ & &
\end{tabular}

Compliance with the growth rate disclosure requirement is lower than that observed for the discount rate with six ( $8 \%$ of 74 ) not providing a growth rate. A further four $(5 \%)$ reported a growth rate but it was not clear, from the descriptions used, whether the growth rate related to the 
extrapolated cash flows or the period covered by management budgets. As with the discount rate the overall compliance by 64 (86\% of 74) is classified into clear compliance by 37 (50\% of 74) and ostensible compliance by 27 (36\%). Similar considerations to those adopted for the discount rates were used in assessing clear or ostensible compliance. Clear compliance is indicated where each CGU disclosed had a unique growth rate. It was also indicated where a growth rate was not relevant as there was no terminal period which was the case with the two mining entities and an entity projecting cash flows over the life of the contract. In contrast, ostensible compliance is assessed where entities reported a range of growth rates suggesting that disclosure was not at the level that the impairment test was conducted (11). Others provided a single growth rate for all CGUs (11) or provided individual growth rates which were all the same (four). In one instance the growth rates were by geographic area rather than the reported units.

Paragraph 134(d)(iv) requires the entity to justify growth rates that exceed the long-term average for the applicable product, industry, country, or market but does not explicitly require the entity to indicate whether or not the growth rate used does not exceed the appropriate benchmark. As a result, it is not possible to assess whether no comment means that the growth rate is below the long-term average or the entity has merely chosen to ignore the requirement. This was the case for $30(49 \%)$ of the 61 entities reporting growth rates with $31(51 \%)$ providing a positive assertion that the growth rate was conservative or did not exceed long-term trends. It is suggested that the confidence with which users reviewed the growth rate would be enhanced if more entities adopted this practice.

\subsection{Cash flow assumptions}

Table 7 below presents an assessment of the information value of cash flow assumptions if any, provided by the entities in the sample. The disclosures were reviewed and classified as none, minimal, some or meaningful. This classification is, of necessity, judgemental so the following guidance is provided as to the approach followed. None was awarded where there was no attempt

to describe or discuss any factors. Minimal was awarded in cases where a cursory comment was provided, typically related to the indicators (sales, expenses, margins) rather than the drivers (economic growth, competitor activity, consumer sentiment, raw material process). Some and meaningful were awarded where drivers were presented - some provided brief coverage whereas 
more comprehensive coverage was required to be considered meaningful.

$\underline{\text { Table } 7 \text { - VIU cash flow assumptions }}$

\begin{tabular}{|c|c|}
\hline Good or some effort at disclosure & 19 \\
\hline Meaningful - comprehensive coverage afforded key drivers of cash flows & 10 \\
\hline Some - brief coverage afforded key drivers of cash flows & 9 \\
\hline Weak or no effort at disclosure & 55 \\
\hline Minimal - cursory comment typically covering indicators not drivers & 39 \\
\hline None - no attempt at factors other than discount and growth rates & 16 \\
\hline Total VIU entities & 74 \\
\hline
\end{tabular}

The vast majority of reporting entities either made no attempt or any substantive effort to provide meaningful information on the assumptions underpinning the cash flows. Typically, what is provided as assumptions is the information on cash flow periods, terminal value growth rate, and discount rates required by paragraphs $134(\mathrm{~d})(\mathrm{iii}-\mathrm{V})$. This is consistent with the finding of the Financial Reporting Council (2017) in the United Kingdom that discount and growth rates are often the only key assumptions provided. Paragraph 134(d)(i) clearly requires disclosure of the key assumptions on which management has based its cash flow projections. IAS 36 contains an illustrative example of the types of information that would be expected to comply with these disclosure requirements (IASB, 2018a). These are budgeted gross margins, government bond rates, currency exchange rates, raw materials price inflation, and budgeted market share. BC209 clarifies that the IASB is not expecting the values associated with the assumptions be provided but rather a description and discussion is sufficient.

Weak or no effort at disclosure was observed for 55 (74\% of 74) entities. A majority, 39 (53\%) of the 74 entities provided minimal disclosures on the assumptions with 9 (12\%) providing no indication of the assumptions underpinning the cash flow projections. Good or some effort at disclosure was assessed for 19 (26\% of 74$)$. Some disclosures were provided by 9 (12\%) entities and $10(14 \%)$ entities provided a meaningful level of disclosure on the factors driving the cash flows. It is argued that this, most neglected of the disclosure requirements, is actually the most relevant to users of financial statements - in the absence of robust cash flow projections the validity of the VIU model is compromised. It is proposed that this requirement could be readily complied 
with for any well-run organisation - the budgeting process common to most companies would require an assessment of these key assumptions prior to executing the budget process.

\section{Conclusions}

Goodwill is a material asset for the majority of the population of 133 South African entities comprising the JSE All Share Index - $83(62 \%)$ have a goodwill balance in excess of 1\% of total assets and $27(20 \%)$ have goodwill balances comprising more than $10 \%$ of total assets. Goodwill on average represents $12 \%$ of the market capitalisation of South African entities.

$78(94 \%)$ of the 83 entities appeared to comply with the requirement to report the goodwill allocated to CGUs although the effective compliance is lower when unclear disclosures and instances of disclosure at a higher level than the actual impairment testing are considered. Such consolidated reporting can result in the reporting of wide ranges for discount rates and growth rates considered to be meaningless to users of the financial reports.

The predominant method used to calculate recoverable amount was VIU, with 74 (91\% of the 81 reporting entities) using VIU. It is not clear whether this was in fact the higher of VIU and FVLCD or the only method used. The apparent $86 \%$ rate of compliance by 64 of the 74 VIU entities with the requirement to disclose the growth rate used for the period after management's budgets was noted to mask a higher rate of ineffective compliance due to disclosure of single rates for all CGUs and a, often wide, range of rates. The gap between effective and apparent compliance was even higher for the requirement to disclose the discount rate used. Although only one entity did not disclose the rate used, the effective rate of compliance declined to $62 \%$ (46 of 74 VIU entities) when adjusted for the reporting of single rates for all CGUs or ranges of discount rates. Use of a post-tax rate, directly counter to the required pre-tax rate, was disclosed by $6(8 \%)$ of the 74 VIU entities reviewed.

The weakest compliance was seen in, what, it is proposed, is the most useful information to users

and readily accessible to preparers, the requirement to disclose the key assumptions used to determine the cash flow projections. The majority, 55 (74\%) of the 74 VIU entities, provided no, 
or minimal, essentially meaningless, disclosures.

The overall level of compliance with the requirements of paragraph 134 is assessed to be poor despite the materiality of goodwill to a majority of the entities. This is consistent with the observation of the JSE in their reports of the proactive monitoring of financial statements. In both 2017 (JSE, 2018b) and 2018 (JSE, 2019) the disclosures required by IAS 36 paragraphs 130 to 134 were listed as the second most commonly omitted disclosures. The causes of this noncompliance are not known but can be speculated to be: a lack of knowledge and understanding of the detailed requirements; disregard of the requirements either in an attempt to thwart too close a review of goodwill and the impairment testing process or in the belief that these disclosures are of no, or limited, use to their stakeholders and are therefore not justified on a cost-benefit basis.

This paper seeks to provide an initial perspective for a deeper analysis of the reliability of the value of goodwill in the financial statements of South African entities. It is suggested that answers to the following six questions would support a deeper understanding of the reliability of goodwill accounting. One; to what degree are South African entities complying with the disclosure requirements of paragraph 130 (distinct from the paragraph 134 disclosures reviewed in this paper which relate to the annual testing process) when an impairment loss is recognised in the accounting period? Paragraph 130 disclosures, which are only applicable when an impairment is recognised require disclosure of the events and circumstances that led to the impairment loss. Two; do financial analysts find the disclosures mandated by paragraph 134 that were reviewed in this paper to be of value in evaluating the reliability of goodwill? Allied to this question, what other metrics do financial analysts use to assess whether the carrying amount of goodwill is supported by the entity's financial outlook? Three; do indications of delayed or avoided impairments exist in the South African environment similar to those seen in other jurisdictions? Four; does the market reaction to impairment events suggest that the market places reliance on the impairment test or alternatively the market has already recognised the economic impairment ahead of the accounting impairment event? Five; do the values disclosed seem appropriate and reasonable in comparison to the values disclosed by peer entities? Six; what impact, if any, appears to be exerted by the choice of auditor on the observations derived from these questions? Answers to these questions would be expected to provide meaningful insights into the reliability of goodwill accounting, 
specifically, and financial reporting more generally, in South Africa.

\section{References}

Australian Securities \& Investments Commission (ASIC) (2017). Media release 17-423.

Retrieved from https://asic.gov.au/about-asic/news-centre/find-a-media-release/2017releases/17-423mr-asic-calls-on-preparers-to-focus-on-financial-report-quality-and-newrequirements/

Bloom, M. (2008). Double Accounting for Goodwill. Abingdon: Routledge.

Carlin, T. \& Finch, N. (2007). Towards a Theory of Goodwill Impairment Testing Choices under IFRS. Journal of Theoretical Accounting Research, 3(1), 74-95.

Carlin, T. \& Finch, N. (2011). Goodwill impairment testing under IFRS: a false impossible shore? Pacific Accounting Review, 23(3), 368-392.

Carlin, T., Finch, N. \& Ford G. (2007). Goodwill Impairment - An Assessment of Disclosure Quality and Compliance Levels by Large Listed Australian Firms. Retrieved from https://papers.ssrn.com/sol3/papers.cfm?abstract_id=963078

Carvalho, C., Rodriques, A. \& Ferreira, C. (2016). Goodwill \& Mandatory Disclosure Compliance: A Critical Review of the Literature. Australian Accounting Review, 26(4), 376-389.

Crotty, A. (2019, August 8). Auditors Under Fire. Financial Mail, 20-25.

D'Alauro, G. (2013). The impact of IAS 36 on goodwill disclosure: Evidence of the write-offs \& performance effects. Intangible Capital, 9(3), 754-799.

Darrough, M., Guler, L. \& Wang, P. (2014). Goodwill Impairment Losses \& CEO Compensation. Journal of Accounting, Auditing \& Finance, 29(4), 435-463.

Eilifsen, A. \& Messier, W. (2015). Materiality Guidance of the Major Public Accounting Firms. Auditing: A Journal of Practice \& Theory. 34(2), 3-26.

Eloff, A. \& De Villiers, C. (2015). The value-relevance of goodwill reported under IFRS 3 versus IAS 22. South African Journal of Accounting Research, 29(2), 162-176.

European Financial Reporting Advisory Group (EFRAG) (2014). Should Goodwill Still Not Be Amortised? Accounting and Disclosure for Goodwill. Retrieved from 
http://old.efrag.org/files/Goodwill\%20Impairment\%20\&\%20Amortisation/140725_Should _goodwill_still_not_be_amortised_Research_Group_paper.pdf

European Securities and Markets Authority (ESMA) (2012). 12th Extract from the EECSs

Database of Enforcement. Retrieved from https://www.esma.europa.eu/document/12thextract-eecs $\% \mathrm{E} 2 \% 80 \% 99$ s-database-enforcement

European Securities and Markets Authority (ESMA) (2013). European enforcers review of impairment of goodwill and other intangible assets in the IFRS financial statements.

Retrieved from https://www.esma.europa.eu/document/european-enforcers-reviewimpairment-goodwill-and-other-intangible-assets-in-ifrs-financial

European Securities and Markets Authority (ESMA) (2014). 15th Extract from the EECSs

Database of Enforcement. Retrieved from https://www.esma.europa.eu/document/15thextract-eecs $\% \mathrm{E} 2 \% 80 \% 99$ s-database-enforcement

EY (2017), International GAAP 2017, Chichester: Wiley.

Financial Reporting Council (FRC) (2017). Corporate Reporting Review Technical Findings

2016/17. Retrieved from https://www.frc.org.uk/getattachment/8e7f626e-d69a-42a1-8a0a35be1ea8a9c4/Corporate-Reporting-Review-Technical-findings-2017.pdf

Ford, J. (2018, May 6). The real cost of optional goodwill impairments. The Financial Times. Retrieved from https://www.ft.com/content/761a90ee-5119-11e8-b3ee-41e0209208ec

FTSE Russell (2019). Factsheet - FTSE/JSE All-Share Index. Retrieved from https://www.ftserussell.com/analytics/factsheets/Home/Search

Glaum, M., Schmidt, P., Street, D. \& Vogel, S. (2013). Compliance with IFRS 3- \& IAS 36required disclosures across 17 European countries: company- and country-level determinants. Accounting and Business Research, 43(3), 163-204.

Hoogervorst, H. (2012, September 18). The Concept of Prudence: dead or alive? Proceedings of the FEE Conference on Corporate Reporting of the Future, Brussels, Belgium. Retrieved from https://www.ifrs.org/-/media/feature/news/speeches/2012/hans-hoogervorst-feeseptember-2012.pdf

International Accounting Standards Board (IASB) (2018a). International Financial Reporting Standards - Official pronouncements issued at 1 January 2018. IFRS Foundation Publications Department, London. 
International Accounting Standards Board (IASB) (2018b). Staff Paper: Goodwill and Impairment research project -Value in use: cash flows from a future restructuring or a future enhancement. Retrieved from https://www.ifrs.org//media/feature/meetings/2018/january/iasb/ap18b-g-and-i-cash-flows.pdf

Ji, K. (2013). Better Late than Never, the Timing of Goodwill Impairment Testing in Australia. Australian Accounting Review, 23(4), 369-379.

Johannesburg Stock Exchange (JSE) (2017). Report Back on Proactive Monitoring of Financial Statements in 2016. Retrieved from https://www.jse.co.za/content/JSEStatementsReviewsandReportsItems/February\%202019 \%20Report\%20Back\%20on\%20Proactive\%20Monitoring\%20of\%20Financial\%20Stateme nts.pdf

Johannesburg Stock Exchange (JSE) (2018a). 20181224 December Quarterly Index Review Paper Market. Retrieved from https://www.jse.co.za/services/market-data/indices/ftse-jseafrica-index-series

Johannesburg Stock Exchange (JSE) (2018b). Report Back on Proactive Monitoring of Financial Statements in 2017. Retrieved from https://www.jse.co.za/content/JSEStatementsReviewsandReportsItems/Report\%20Back\%2 0on\%20Proactive\%20Monitoring\%20of\%20Financial\%20Statements\%20in\%202017.pdf Johannesburg Stock Exchange (JSE) (2019). Report Back on Proactive Monitoring of Financial Statements in 2018. Retrieved from https://www.jse.co.za/content/JSEStatementsReviewsandReportsItems/February\%202019 \%20Report\%20Back\%20on\%20Proactive\%20Monitoring\%20of\%20Financial\%20Stateme nts.pdf

Kabir, H., Rahman, A. \& Su, L. (2017, January 18). The Association between Goodwill Impairment Loss and Goodwill Impairment Test-Related Disclosures in Australia. Proceedings of the 8th Conference on Financial Markets and Corporate Governance, Wellington, New Zealand. Retrieved from https://papers.ssrn.com/sol3/papers.cfm?abstract_id=2901397\#\#

Lex (2010, September 27). Excessive goodwill. The Financial Times. Retrieved from https://www.ft.com/content/8f382e48-ca2a-11df-87b8-00144feab49a 
Mazzi, F., André, P., Dionysiou, D. \& Tsalavoutas, I. (2017). Compliance with goodwill-related mandatory disclosure requirements and the cost of equity capital. Accounting and Business Research, 47(3), 268-312.

Omarjee, F. \& Garnett, R. (2017, June 28-30). The value relevance of goodwill under IFRS 3: a South African context. Proceedings of the 2017 Southern African Accounting Association Biennial International Conference, Drakensberg, South Africa. Retrieved from http://www.saaa.org.za/Downloads/Publications/FAC017\%20The\%20value\%20relevance \%20of\%20goodwill\%20under\%20IFRS3_A\%20SA\%20context.pdf

Ontario Securities Commission (OSC) (2014). OSC Staff Notice 52-721. Retrieved from https://www.osc.gov.on.ca/en/SecuritiesLaw_sn_20130920_52-721_oca-financialreporting-bulletin.htm

Ramanna, K. \& Watts, R. (2012). Evidence on the Use of Unverifiable Estimates in Required Goodwill Impairment. Review of Accounting Studies, 17(4), 749-780.

The Economist (2013, May 18). Goodwill hunting. Retrieved from https://www.economist.com/business/2013/05/18/goodwill-hunting Tradehold Ltd (2018). Integrated Report 2018. Retrieved from https://www.tradehold.co.za/docs/annual_report/6028\%20Tradehold\%20IR\%202018.pdf 